\title{
Method for Determining General Toxicity of Phytobiotics from Extracts of Medicinal Plants
}

\author{
Elena V. ULRICH \\ Ph.D. (in Technical Sciences) \\ Professor \\ Department of Agrobiotechnology \\ Kuzbass State Agricultural Academy \\ 5, Markovtsev Str., Kemerovo, 650056, Russian Federation \\ 7(904)9609496 \\ elen.ulrich@mail.ru \\ Oksana V. SMOLOVSKAYA \\ Ph.D. (in Biology Sciences) \\ Associate Professor \\ Department of Agrobiotechnology \\ Kuzbass State Agricultural Academy \\ 5, Markovtsev Str., Kemerovo, 650056, Russian Federation \\ Artem E. TOLSTOY \\ $2^{\text {nd }}$ year student of Agrobiotechnology Faculty \\ Kuzbass State Agricultural Academy \\ 5, Markovtsev Str., Kemerovo, 650056, Russian Federation
}

\section{Abstract}

The results described in the article make it possible to objectively evaluate the general toxicity for living organisms of experimental lots of phytobiotic feed additives based on extracts of medicinal plants. Experimental batches of phytobiotic feed additives based on extracts of medicinal plants in the amount of 24 species from 12 medicinal plants of $1000 \mathrm{~g}$ each, obtained under optimal technological conditions for each plant, were selected according to preliminary tests of the technological process for the production of experimental batches of phytobiotic feed additives based on extracts of medicinal plants, in accordance with the laboratory and technological regulations of the technological process for the production of pilot batches of phytobiotic feed additives. The accumulated experimental batches of phytobiotic feed additives, based on extracts of medicinal plants for preliminary tests in accordance with the pilot industrial technological procedure for the production process of phytobiotic feed additives based on extracts of medicinal plants, are suitable for ecotoxicity tests. There were studied 12 experimental batches of phytobiotic feed additives based on extracts of medicinal plants (from 12 medicinal plants). The concentration of the studied aqueous solution of phytobiotic feed additives was 5\%. The survival of ceriodaphnia crustaceans in the control was $93 \%$.

Keywords: general toxicity; phytobiotic feed additives; medicinal plants; crustaceans; extracts. 


\section{Introduction}

In recent years, the high biological activity of many phytobiotic feed additives based on extracts of medicinal plants has been identified, which led to the creation of effective antibacterial, antifungal, antitumor and other preparations (Dhadse et al., 2009).

Of scientific and practical interest is the study of the possibility of using new substances as feed additives (Moun et al., 2016). It is known that the target of a feed additive action is mostly farm animals and poultry.

To ensure environmental safety of newly synthesized phytobiotic feed additives intended for use as biologically active substances, an eco-toxicological assessment is required, which includes studying the effect of their effects on test objects that use daphnia, luminous bacteria, protozoa, and algae.

During bio-testing, acute and chronic toxicity of controlled objects for living organisms is determined.

Toxicity is the degree of toxic effect manifestation of various compounds and their mixtures that damage, suppress, cause stress, cause genetic changes or kill organisms in water, soil and air (Rodgher, Espíndola, 2008).

As a toxicity criterion, a significant quantitative change in the test parameter is taken, on the basis of which a conclusion is made about the toxicity of a substance, water or soil. Among the test parameters, mortality, survival, fertility, suppression of enzymatic activity and other functions of the tested organisms are most often used.

A test reaction is a change in any morphological, biochemical, behavioral or functional indicator of a tested object under the influence of toxic substances contained in a test environment.

During bio-testing, acute or chronic toxicity of the test medium is usually established in experiments of various durations.

Acute experience is a short-term bio-testing procedure (with exposure time set in each method), determining acute toxicity at $50 \%$ of the survival (mortality) of the tested objects. Acute toxicity is manifested if the intensity of the influencing factors (agents) is so high that the compensatory and adaptive reactions of the organism do not have time to manifest themselves and die (Ait-Ouazzou et al., 2011).

Chronic test is a lengthy bio-testing procedure (the exposure time is set in each methodology, which is at least $1 / 10$ of the life expectancy of the used test organisms). In each experiment, a statistically significant deviation from control is established in the fecundity or other parameter of the test 
objects used. Chronic toxicity is determined by a less intense, but more prolonged exposure to toxicants (harmful factors). In this case, there is an imbalance between the breakdown and synthesis of substances in the body of the tested objects, the destruction of the genome and the termination of reproduction (Radaelli et al., 2016).

General toxicity - the ability of chemicals acting on a biocenosis to cause damage or death. Substances differ in toxic action (Aubert, 2017). The smaller the amount of substance that can harm the body, the more toxic it is. To determine whether phytobiotic feed additives are toxic to biocenoses, it was necessary to conduct a study of the general toxicity for ceriodaphonium crustacean experimental batches of phytobiotic feed additives based on extracts of medicinal plants. Ceriodaphnia crustaceans grow well, multiply, and represent an ecobiocenosis, according to which the general toxicity of aqueous solutions of phytobiotic feed additives can be studied (Basharat, 2015).

During bio-testing, whole organisms (test organisms) as well as isolated organs, tissues or cells can be used as test objects. The most widely used phytobiotic feed additive bio-testing methods were the ones using such hydrobiont prototypes as: protozoa (ciliates, flagella), intestinal (hydra), worms (planaria, leeches), mollusks (lamellar, gastropods), crustaceans (daphnia), fish, as well as representatives of various groups of plants and algae (Basharat, 2015).

An analysis of the basic laws of the adaptation process of living organisms, the physiological, behavioral, and environmental characteristics of aquatic organisms allows formulating the basic requirements for test organisms and test operations (test functions, test parameters).

Test organisms should meet the following requirements:

- Organisms used for testing should be genetically homogeneous, which will ensure the similarity of their sensitivity and stability, as well as the uniformity of responses to toxicants, guaranteeing high reproducibility of test results;

- The functional activity of the test organism should not have a seasonal periodicity, which will allow you to get the same results regardless of the time of year;

- Species used as test organisms must have a high metabolic rate, which will ensure the speed of their reaction to toxicants and, therefore, the expression of bio-test;

- The tested organisms must be resistant to stress, to actions related to the test procedure, that is, placing them in experimental chambers and making the necessary observations and measurements in and of themselves should not cause their distinct stress reactions. 
Meeting all these requirements can only be ensured if pure lines of the tested organisms are grown in standard, as "environmentally friendly" as possible, optimal conditions for this type.

The purpose of the tests was determination of the total toxicity of experimental batches of phytobiotic feed additives based on extracts of each medicinal plant in the laboratory using ceriodaphnia crustaceans as the test object.

The general toxic effect of phytobiotic feed additives on ceriodaphnia is determined by their mortality during a certain period of exposure. The criterion of general toxicity is the death of $50 \%$ or more of ceriodaphnia within 48 hours in the studied phytobiotic feed additives, provided that the control survival is not lower than $90 \%$ (Boczonadi, 2017). Experiments to determine the total toxic effect establish the following:

- Acute toxicity or average lethal concentration of individual substances (the degree of dilution of phytobiotic feed additives containing mixtures of substances), causing the death of $50 \%$ or more of the tested organisms;

- Harmless (not causing acute toxicity effect) concentration of individual substances (the degree of dilution of phytobiotic feed additives containing mixtures of substances), causing the death of no more than $10 \%$ of the tested organisms (Maziar, Moein, 2017).

\section{Methods}

The object of the current study were experimental lots of phytobiotic feed additives based on extracts of medicinal plants.

In the process, 12 experimental batches of phytobiotic feed additives based on extracts of medicinal plants (from 12 medicinal plants) were investigated.

Determination of the total toxicity of experimental batches of phytobiotic feed additives based on extracts of medicinal plants for living organisms is carried out according to the methodology for determining the ecotoxicity and general toxicity of experimental batches of phytobiotic feed additives based on extracts of each medicinal plant in laboratory conditions using ceriodaphonium crustaceans as an object of testing. This method can be applied to phytobiotic feed additives, since an aqueous solution of phytobiotic feed additives is prepared for analysis. General toxicity is checked at the level of the body (autotoxic properties) - they are manifested by a resistance decrease to other active environmental factors, a decrease in activity, diseases, death of the body, carcinogenesis, impaired reproductive function, etc., as well as on the level of the population (demethoxic properties) - manifested by the death of the population, an increase in morbidity, mortality and a decrease in the birth rate. 
The methodology is based on determining the mortality of ceriodaphnia crustaceans (Ceriodaphnia affinis) under the influence of toxic substances present in the studied solutions of phytobiotic feed additives, compared with the control culture in samples containing no toxic substances (control). The number of living and dead Daphnia is determined by the direct counting method (Rodgher, Espíndola, 2008).

Preparation of glassware for sampling, storage of samples and biotesting, preparation of cultivation water, preparation of source material, transportation, content and yeast-water feeding of ceriodaphnes, growing uterine and synchronized culture, experiments to determine the general toxicity of the technological process. Production of experimental lots of phytobiotic feed additives based on extracts of medicinal plants, processing, evaluation and presentation of the results were carried out in accordance with the methodic PND F T 14.1:2:4.18-2011.

To determine the total toxicity of experimental batches of phytobiotic feed additives based on extracts of medicinal plants, the percentage of dead ceriodaphnia in the test sample $(\mathrm{A}, \%)$ is calculated in comparison with the control (Aubert, 2017, Basharat, 2015).

If $\mathrm{A}<10 \%$, the tasted phytobiotic feed additives based on extracts of medicinal plants do not have a general toxic effect (harmless concentration or harmless dilution factor). If $\mathrm{A}>50 \%$, the tested phytobiotic feed additives based on extracts of medicinal plants have an acute toxic effect (average lethal concentration, lethal dilution) (Singh et al., 2014).

\section{Results}

The general toxicity of phytobiotic feed additives obtained by the method of low-temperature vacuum water-ethanol extraction followed by vacuum low-temperature drying is determined.

Table 1 presents the modes of obtaining phytobiotic feed additives.

Table 1. Production modes of pilot batches of phytobiotic feed additives based on extracts of medicinal plants

\begin{tabular}{|c|c|c|c|c|c|c|}
\hline \multirow[t]{2}{*}{ Plant name } & \multirow[t]{2}{*}{ Temperature, ${ }^{0} \mathrm{C}$} & \multicolumn{3}{|c|}{$\begin{array}{c}\text { Time of water-ethanol } \\
\text { extraction, min }\end{array}$} & \multirow{2}{*}{$\begin{array}{l}\text { Vacuum } \\
\text { depth, } \\
\mathrm{kgf} / \mathrm{cm}^{2}\end{array}$} & \multirow{2}{*}{$\begin{array}{c}\text { Ethanol } \\
\text { concentration, } \\
\%\end{array}$} \\
\hline & & 1 stage & 2 stage & Total & & \\
\hline $\begin{array}{c}\text { Sarepta mustard } \\
\text { (Brassica } \\
\text { juncea L.) }\end{array}$ & 30 & 10 & 20 & 30 & -0.93 & 94 \\
\hline $\begin{array}{l}\text { Stinging nettle } \\
\text { (Urtica dioica) }\end{array}$ & 30 & 10 & 20 & 30 & -0.93 & 25 \\
\hline $\begin{array}{c}\text { Safflower } \\
\text { leuzea } \\
\text { (Rhaponticum } \\
\text { carthamoides } \\
\text { (Willd.)) }\end{array}$ & 30 & 10 & 20 & 30 & -0.93 & 70 \\
\hline
\end{tabular}




\begin{tabular}{|c|c|c|c|c|c|c|}
\hline $\begin{array}{c}\text { Mountain ash } \\
\text { (Sorbus } \\
\text { aucuparia) }\end{array}$ & 30 & 10 & 20 & 30 & -0.93 & 48 \\
\hline $\begin{array}{l}\text { Jerusalem } \\
\text { artichoke } \\
\text { (Helianthus } \\
\text { tuberosus) }\end{array}$ & 30 & 10 & 20 & 30 & -0.93 & 3 \\
\hline $\begin{array}{c}\text { Thyme } \\
\text { (Thymus } \\
\text { serpyllum L.) }\end{array}$ & 30 & 10 & 20 & 30 & -0.93 & 48 \\
\hline $\begin{array}{c}\text { Sowing garlic } \\
\text { (Allium } \\
\text { sativum) }\end{array}$ & 30 & 10 & 20 & 30 & -0.93 & 90 \\
\hline Rosehip (Rosa) & 30 & 10 & 20 & 30 & -0.93 & 32 \\
\hline $\begin{array}{c}\text { Echinacea } \\
\text { purpurea } \\
(\text { Echinacea })\end{array}$ & 30 & 10 & 20 & 30 & -0.93 & 40 \\
\hline $\begin{array}{l}\text { Wild camomile } \\
\text { (Chamomilla } \\
\text { recutita L.) }\end{array}$ & 30 & 10 & 20 & 30 & -0.93 & 3 \\
\hline $\begin{array}{l}\text { Milk Thistle } \\
\text { (Silybum } \\
\text { marianum L.) }\end{array}$ & 30 & 10 & 20 & 30 & -0.93 & 70 \\
\hline $\begin{array}{c}\text { Calendula } \\
\text { officinalis } \\
\text { (Calendula } \\
\text { officinalis L.) }\end{array}$ & 30 & 10 & 20 & 30 & -0.93 & 40 \\
\hline
\end{tabular}

The accumulated experimental batches of phytobiotic feed additives based on extracts of medicinal plants for preliminary tests in accordance with the experimental-industrial technological regulations for the production of phytobiotic feed additives based on extracts of medicinal plants are suitable for ecotoxicity tests.

The results of determining the general toxicity on the example of phytobiotic feed additives based on extracts of medicinal plants are presented in Table 2.

Table 2. The results of determining the general toxicity on the example of phytobiotic feed additives based on extracts of medicinal plants

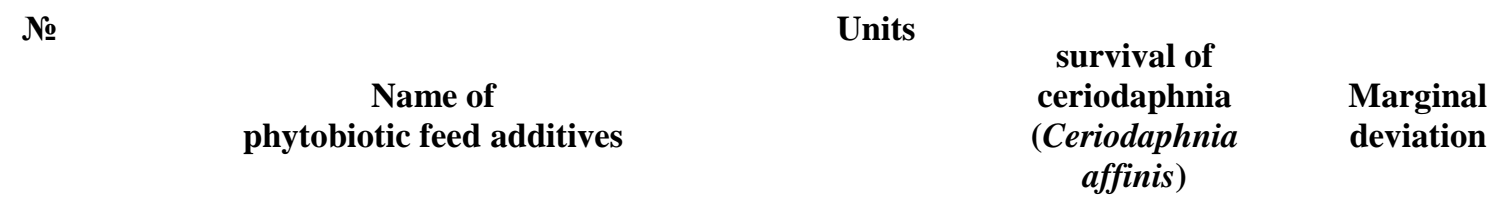

Stinging nettle (Urtica dioica)

2

Sarepta mustard (Brassica juncea L.)
92.3

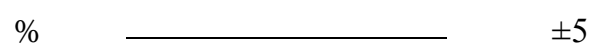

91.0 
3

Safflower leuzea

(Rhaponticum carthamoides (Willd.))

\begin{tabular}{ll}
\hline 4 & \\
& Mountain ash \\
& (Sorbus aucuparia)
\end{tabular}

94.1

$$
5
$$

Jerusalem artichoke

(Helianthus tuberosus)

$$
91.2
$$

$\overline{6}$ Thyme (Thymus serpyllum L.)

Sowing garlic (Allium sativum)

$$
8
$$

Rosehip (Rosa)

$\overline{\text { Echinacea purpurea }(\text { Echinacea })}$

\begin{tabular}{ll}
\hline $10 \quad$ Wild camomile \\
$\quad$ (Chamomilla recutita $L)$.
\end{tabular}

$$
11
$$

Milk Thistle

(Silybum marianum L.)

12

Calendula officinalis

(Calendula officinalis L.)

According to the tabular data it follows that the survival rate of ceriodaphnia (Ceriodaphnia affinis) ranged from 91.0 to $94.5 \%( \pm 5 \%)$

\section{Conclusion}

Thus, when studying the general toxicity of phytobiotic feed additives based on extracts of medicinal plants, a high survival rate of ceriodaphnia (Ceriodaphnia affinis) was established.

\section{References}

Ait-Ouazzou, A., Cherrat, A., Espina, L., Lorán, S., Rota, C., Pagán, R. (2011). The antimicrobial activity of hydrophobic essential oil constituents acting alone or in combined processes of food preservation. Innovative Food Science \& Emerging Technologies, 12, 320-329. DOI: 10.1016/j.ifset.2011.04.004 
IV International Scientific and Practical Conference "Modern S\&T Equipments and Problems in Agriculture"

Aubert, T. (2017). Dairy management: It's all in the feed. Retrieved from: http://www.allaboutfeed.net/Feed-Additives/Articles/2017/6/Dairy-management-Its-all-inthe-feed-143796E/?dossier $=25113 \&$ widgetid=0

Basharat, S. (2015). Antioxidative potential of phytogenics. Retrieved from: https://www2.biomin.net/ru/stati/antioxidative-potential-of-phytogenics/

Boczonadi, A. (2017, July 17). 2 key points to fresh cow profits. Retrieved from: https://www2.biomin.net/ru/stati/two-keys-to-fresh-cow-profits/

Dhadse, S., Sitre, S., Satyanarayan, S. (2009). Toxicity of Herbal Pharmaceutical Wastewater to a Freshwater Crustacean Ceriodaphnia dubia. Bulletin of Environmental Contamination and Toxicology, 82(3), 275-279. DOI: 10.1007/s00128-008-9578-3

Maziar, M-A., Moein, G-R. (2017). Comparison of the effect of two phytogenic compounds on growth performance and immune response of broilers. Journal of Applied Animal Research, 45(1), 603-608. DOI: 10.1080/09712119.2016.1243119

Moun, D.R., Erickson, R.J., Highland, T.L., Hockett, J.R., Hoff, D.J., Jenson, C.T., et al. (2016). The acute toxicity of major ion salts to ceriodaphnia dubia: i. influence of background water chemistry. Environmental Toxicology and Chemistry, 35(12), 3039-3057. DOI: $10.1002 /$ etc.3487

Radaelli, M., Parraga da Silva B., Weidlich L., Hoehne L., Flach A., Mendonca Alves da Costa, L.A., Ethur E.M. (2016). Antimicrobial activities of six essential oils commonly used as condiments in Brazil against Clostridium perfringens. Brazilian Journal of Microbiology, 47, 424-430. DOI: 10.1016/j.bjm.2015.10.001

Rodgher, S., Espíndola, E.L.G. (2008). The influence of algal densities on the toxicity of chromium for Ceriodaphnia dubia Richard (Cladocera, Crustacea). Brazilian Journal of Biology, 68(2), 341-348. DOI: 10.1590/S1519-69842008000200015

Singh, J., Sethi, A.P.S., Sikka, S.S. (2014). Effect of Cinnamon (Cinnamomum cassia) Powder as a Phytobiotic Growth Promoter in Commercial Broiler Chickens. Animal nutrition and feed technology, 14(3), 471-479. DOI: 10.5958/0974-181X.2014.01349.3 